\title{
Bioprospecting of Bioactive Metabolites from Monochaetia karstenii
}

\author{
Yogeswari Subramaniam ${ }^{1 *}$ (D), Ramalakshmi Subbiah ${ }^{2}$ (D), \\ Leeba Balan ${ }^{1}$ (D) and Kamalraj Subban ${ }^{1}$
}

${ }^{1}$ Centre for Advanced Studies in Botany, University of Madras, Maraimalai Campus, Guindy, Chennai - 600025 , Tamil Nadu, India. '2Department of Microbiology, Sri Moogambigai Arts and Science College for Women, PalacodeHosur Main Road, Thimmarayanahalli PO, Mallupatti, Dharmapuri Dst. - 636 805, Tamil Nadu, India.

\begin{abstract}
In the present study, to optimize the media for the production of bioactive compounds from Monochaetia karstenii was carried out and compounds were identified by GC-MS. M. karstenii was identified from infected Camellia japonica leaves by classical and molecular taxonomy. It was cultured in different media and determined their mycelial biomass and antibacterial activity. Further Maltose Maltose tartrate broth (MTB) was altered for its media components such as carbon, nitrogen, minerals, amino acids and vitamins sources and physical parameters like temperature, $\mathrm{pH}$ and incubation periods for growth and production of secondary metabolites from $M$. karstenii. The antimicrobial and antioxidant compounds were performed from three different solvent extracts (Chloroform, Dichloromethane and Ethyl acetate) of $M$. karstenii from optimized medium. $M$. karstenii had optimum growth in MTB showing mycelial growth of $13.16 \mathrm{~g} / \mathrm{L}$. The ethyl acetate extract observed significant antibacterial activity against Escherichia coli $(21 \mathrm{~mm})$, Staphylococcus aureus $(20 \mathrm{~mm})$ and Vibrio chloreae $(18 \mathrm{~mm})$. In-vitro antioxidant activity revealed that, the $\mathrm{IC}_{50}$ values for 2, 2'-azino-bis (3-ethylbenzothiazoline-6-sulphonic acid (ABTS), 2, 2-diphenyl-1-picrylhydrazyl (DPPH) and total antioxidant radical scavenging assay of $100.58 \mu \mathrm{g} / \mathrm{ml}, 140 \mu \mathrm{g} / \mathrm{ml}$ and $141.91 \mu \mathrm{g} / \mathrm{ml}$ from ethyl acetate extract respectively. Thus the antimicrobial and antioxidant activity of the fungal extract has been due to the presence of biocompounds such as cyclohexenone derivatives, cinnamic acid, isooxazoline 3-phenyl- benzodiazepine, 2- propenoic acid 3-phenyl-(E)-dodecene and 3-undecen -1-yne (E) were characterized by gas chromatography-mass spectrometry (GC-MS) and reported first time in $M$. karstenii. We conclude that $M$. karstenii possess excellent antimicrobial and antioxidant potential and can be exploited for the discovery of new drug molecules.
\end{abstract}

Keywords: Monochaetia karstenii, anti-bacterial, antioxidant, GC-MS analysis, media optimization, cinnamic acid

\footnotetext{
*Correspondence: chithra.yogi30@gmail.com; +91 9880302458.
}

(Received: February 07, 2020; accepted: June 6, 2020)

Citation: Subramaniam Y, Subbiah R, Balan L, Subban K. Bioprospecting of Bioactive Metabolites from Monochaetia karstenii. J Pure Appl Microbiol. 2020;14(2):1557-1566. doi: 10.22207/JPAM.14.2.54

(C) The Author(s) 2020. Open Access. This article is distributed under the terms of the Creative Commons Attribution 4.0 International License which permits unrestricted use, sharing, distribution, and reproduction in any medium, provided you give appropriate credit to the original author(s) and the source, provide a link to the Creative Commons license, and indicate if changes were made. 


\section{INTRODUCTION}

Fungi has been the source of most profitable industrial products used for medicine such as two anti-cholesterol strains, antibiotic penicillin and immunosuppressant cyclosporine A. Media and growth conditions such as $\mathrm{pH}$, temperature optimization is most necessary for high production of bioactive compounds ${ }^{1}$. Secondary metabolites are excreted out of cell protect the fungi from extreme conditions, competitors and also help in survival ${ }^{2,3}$. There is always a search for novel drug molecules from different sources. There are limited studies on plant pathogenic fungi as source of secondary metabolites which are unexplored ${ }^{4}$. Various studies have showed that altering the growth environment has major effect on the production of fungal secondary metabolites ${ }^{5,6}$. Moreover, the carbon and nitrogen sources leads for fungal growth and secondary metabolites production. A report showed that nitrogen sources had a biggest impact in studies conducted on three genera of Entomophthorales ${ }^{7}$. Whereas the environmental factors such as growth factors, $\mathrm{pH}$, moisture, temperature, pressure, incubation period, are most deciding factors for antibiotic biosynthesis ${ }^{8}$.The requirements of nutritional conditions vary from fungus to fungus depending upon the genera to which they belong'.

The genera Monochaetia, Pestalotia and Pestalotiopsis have similar conidia provided with apical appendage. Monochaetia differs from the latter two genera with conidia, septate and a single apical appendage. Species in the genus are typically plant parasites, saprophytes and cause leaf spot diseases on various hosts ${ }^{10}$. However most of the Monochaetia species lack molecular data $^{11}$ and it may be a rare occurrence and distribution. Monochaetia species are observed to produce bioactive compounds like taxol, ambuic acid and chaetiacandin ${ }^{12-14}$. In our previous study, we reported diverse volatile fractions from Monochaetia kansensis showing presence of bioactive compound phenol, 2, 4-bis (1,1- dimethyl ethyl). The comparative study among different extraction, ethyl acetate extract possessed good yield of bioactive compounds ${ }^{15}$. So far there is no report in $M$. karstenii for optimization of culture conditions. Therefore, the current study aimed for determination of optimum growth of $M$. karstenii for their production of bioactive secondary metabolites and characterization of bioactive compounds.

\section{MATERIALS AND METHODS}

Isolation, molecular identification of $M$. karstenii $M$. karstenii was isolated from infected leaves of Camellia japonica L. from Kodaikanal, Tamil Nadu, India. Classical identification was followed by Sutton ${ }^{16}$ and molecular identification was carried out from the isolated genomic DNA using standard method ${ }^{17}$. The genomic DNA was amplified by thermal PCR condition with help of ITS1 and ITS4 rDNA gene primer. The PCR product was sequenced, compared by $n$ BLAST analysis and identified by species level. Further rDNA sequence of $M$. karstenii was aligned by Clustal-W and analysed for phylogenetic tree using by MEGA6 software with maximum parsimony method ${ }^{18}$.

M. karstenii growth and antibacterial activity in different liquid media

About $100 \mathrm{ml}$ of Cornmeal Peptone yeast extract (CPYEB), Czapexdox broth-I, II (CDB-I), CDB-II, Malt extract broth (MEB), Oat Meal broth (OMB), Maltose tartrate broth (MTB), Potato carrot broth (PCB), Modified 1 medium broth (M1DB), Potato Dextrose Broth (PDB), Crabill's medium, Potato Dextrose Yeast Extract Broth (PDYEB) and Sabouraud Dextrose Broth (SDB) were separately prepared. Three mycelial discs $(10 \mathrm{~mm})$ of $M$. karstenii was inoculated in to the respective media containing flask individually under the influence of $12 \mathrm{~h}$ light followed by $12 \mathrm{~h}$ dark condition (per day). After 21 days of incubation cultures were harvested. In order to measure the fungal biomass dry weight, mycelial mat was filtered through filter paper and dried for $12 \mathrm{hrs}$ at $50^{\circ} \mathrm{C}$. Initial screening such as antibacterial studies were carried out using twelve different culture filtrates against $S$. aureus and Klebsiella pnemoniae by agar well diffusion method $^{19}$. Briefly, bacterial cultures speared on Nutrient Agar medium separately and well (0.5 $\mathrm{cm}$ ) was created using sterile corkborer. To each wells, $100 \mu \mathrm{l}$ of each different culture filtrates were added and incubated at $37^{\circ} \mathrm{C}$ for $24 \mathrm{hrs}$. The development of inhibition zone was measured.

Growth of $\boldsymbol{M}$. karstenii in different chemical and physical conditions

The different media components of carbon sources (20g/L): sucrose, glucose, dextrose, 
maltose, fructose, galactose, lactose, xylose, sorbitol and mannitol; nitrogen sources $(2.8 \mathrm{~g} / \mathrm{L})$ : ammonium nitrate $\left(\mathrm{NH}_{4} \mathrm{NO}_{3}\right)$, yeast extract, beef extract, peptone, potassium nitrate $\left(\mathrm{KNO}_{3}\right)$, urea $\left(\mathrm{CH}_{4} \mathrm{~N}_{2} \mathrm{O}\right)$, ammonium tartrate $\left(\mathrm{C}_{4} \mathrm{H}_{12} \mathrm{~N}_{2} \mathrm{O}_{2}\right)$, ammonium sulphate $\left(\left(\mathrm{NH}_{4}\right)_{2} \mathrm{SO}_{4}\right)$, and sodium nitrate $\left(\mathrm{NaNO}_{3}\right)$; minerals $(0.5 \mathrm{~g} / \mathrm{L})$ : manganese chloride $\left(\mathrm{MnCl}_{2}\right)$, calcium nitrate $\left(\mathrm{Ca}\left(\mathrm{NO}_{3}\right)_{2}\right)$, sodium chloride $(\mathrm{NaCl})$, magnesium sulphate $\left(\mathrm{MgSO}_{4}\right)$, copper sulphate $\left(\mathrm{CuSO}_{4}\right)$, potassium chloride $(\mathrm{KCl})$, zinc sulphate $\left(\mathrm{ZnSO}_{4}\right)$, sodium sulphate $\left(\mathrm{Na}_{2} \mathrm{SO}_{4}\right)$, ferrous sulphate $\left(\mathrm{FeSO}_{4}\right)$, and potassium iodide (KI); amino acid $(50 \mathrm{mg} / \mathrm{L})$ : histidine, glycine, alanine, cysteine, methionine, tryptophan, aspartic acid, phenylalanine and threonine; vitamin sources (50mg/L): Vitamin B1, B2, B6, B8 and B9 ;Physical parameters such as $\mathrm{pH}$ 5.0, 5.5, 6.0-7.0, 7.5 and 8.0; incubation period $5,7,9,11,13,15,17,19,21,23,25$ and 27 days were selected for optimization processes ${ }^{13,20}$. These conditions were used for optimization process in terms of mycelial dry weight.

Mass cultivation and preparation of different fungal extracts

A 15 days old culture of ten mycelial discs $(10 \mathrm{~mm})$ were inoculated in 5 litre Hoffkin flask containing two litre of optimized medium (magnesium sulphate $-0.5 \mathrm{~g} / \mathrm{l}$, yeast extract $2.8 \mathrm{~g} / \mathrm{l}$, glucose $-20 \mathrm{~g} / \mathrm{l}$, potassium dihydrogen phosphate $-1 \mathrm{~g} / \mathrm{l}$, trace elements (Zinc $-0.2 \mathrm{mg} / \mathrm{l}$, Iron $-0.2 \mathrm{mg} / \mathrm{l}$, manganese $-0.1 \mathrm{mg} / \mathrm{l}$ ) and histidine $-50 \mathrm{mg} / \mathrm{l}$ with $\mathrm{pH} 6.8$, under the influence of 12 $\mathrm{h}$ light followed by $12 \mathrm{~h}$ dark condition (per day) for incubation. The fungal culture filtrate was filtered after 21 days and extracted with double the volume of chloroform, dichloromethane and ethyl acetate separately. The each organic solvent extracts were condensed by vacuum rotary evaporator at $40^{\circ} \mathrm{C}$, all organic extracts were dissolved in $0.4 \%$ Dimethyl sulfoxide (DMSO) and it used for bio-assays separately.

\section{Biological activity of $M$. karstenii extracts Antibacterial activity}

Different Solvent extracts (Choloroform, Dichloromethane and Ethylacetate) of $M$. karstenii and $0.4 \%$ DMSO served as a control were analysed their antibacterial activity by agar well diffusion method against S. aureus, E. coli and V. cholera ${ }^{19}$. Total antioxidant radical scavenging assay

Total antioxidant radical scavenging assay carried out using standard method ${ }^{21}$. Fungal ethyl acetate extract with varying concentrations $(75-200 \mu \mathrm{g} / \mathrm{ml}$ ) of $0.2 \mathrm{ml}$ and standard (Ascorbic acid) separately, distilled water $(1.8 \mathrm{ml}), 1 \mathrm{ml}$ of Phosphomolybdenum reagent solution (0.6 $M$ sulphuric acid, $28 \mathrm{mM}$ sodium phosphate and $4 \mathrm{mM}$ ammonium molybdate) were added, incubated at $95^{\circ} \mathrm{C}$ for $90 \mathrm{~min}$ and cooled to $37^{\circ} \mathrm{C}$. The absorbance of each solution was recorded at $695 \mathrm{~nm}$. The result was calculated as percentage of inhibition which is ratio of (absorbance of control solution minus sample solution) to absorbance of control multiplied by 100 and same as was followed for other assays.

\section{ABTS radical scavenging assay}

Fresh ABTS solution (1.8 $\mathrm{mM}$ ) containing $5.0 \mathrm{ml}$ of $4.9 \mathrm{mM}$ potassium persulphate solution to $5.0 \mathrm{ml}$ of $14 \mathrm{mM}$ ABTS solution, diluted to have absorbance of $0.650 \pm 0.20$ at $734 \mathrm{~nm}^{22}$. About $50 \mu \mathrm{l}$ of fungal test sample at concentrations of $10-110 \mu \mathrm{g} / \mathrm{ml}$ and $950 \mu \mathrm{l}$ of ABTS radical solution, standard (Ascorbic acid) were tested individually and absorbance read at $734 \mathrm{~nm}$ and calculated.

\section{DPPH assay}

Ethyl acetate fungal extract and standard (Quercetin) were measured the DPPH assay by standard method ${ }^{23}$. The reaction mixture containing $1.0 \mathrm{ml}$ of $0.1 \mathrm{mM}$ DPPH methanol solution and $50 \mu \mathrm{l}$ of different concentrations of fungal ethyl acetate extract at concentration of $10-150 \mu \mathrm{g} / \mathrm{ml}$, incubated for 30 minutes, absorbance was recorded at $517 \mathrm{~nm}$ and DPPH radical scavenging activity was calculated.

\section{Bioactive compounds from $M$. karstenii extract}

Ethyl acetate extract ( $2 \mu \mathrm{l}$ ) of $M$. karstenii was subjected to GC/MS analysis in GC Clarus 500 Perkin Elmer system with AOC-20i autosampler, gas chromatograph-mass spectrometer. Elite-1 fused silica capillary column of Dimethyl poly siloxane $(30 \times 0.25 \mathrm{~mm}$ ID $\times 1 \mathrm{EM} \mathrm{df}), 70$ $\mathrm{eV}$ electron impact, helium as carrier gas, flow rate of $1 \mathrm{ml} / \mathrm{min}, 0.5 \mathrm{El}, 250^{\circ} \mathrm{C}, 280^{\circ} \mathrm{C}$ used as injection volume, injector temperature and ion-source temperature respectively. The oven temperature was programmed from $110^{\circ} \mathrm{C}$ (isothermal for $2 \mathrm{~min}$ ), with an increase of $10^{\circ} \mathrm{C}$ / min, to $200^{\circ} \mathrm{C} / \mathrm{min}$, then $5^{\circ} \mathrm{C} / \mathrm{min}$ to $280^{\circ} \mathrm{C} / \mathrm{min}$. Mass spectra recorded $(70 \mathrm{eV})$ for interpretation using the database of national institute of standard technology (NIST) mass spectral library. 


\section{Statistical analysis}

Data are given as mean \pm S.E.M with three triplicate values. Statistical comparisons were made using one way ANOVA followed by Tukey's family error test. P-value $<0.05$ was considered as significant.

\section{RESULTS AND DISCUSSION}

Fungi have been always the potential source of novel metabolites for curing various diseases ${ }^{24}$.In this study, fungus was isolated from C. japonica and identified as a M.karstenii. The genus belonging to the order of Melanconiales in imperfect fungi of Coelomycetes ${ }^{25}$, based on conidial structure by classical taxonomy with following descriptions. Mycelia on media was yellow (mature) and white (young) colour (Fig. 1a); Conidiomata acervular; Conidia with thick walls, 4-celled or 3 celled, $13 \times 6.5 \mu \mathrm{m}, 10-5 \mu \mathrm{m}$ long, hyaline, 1-2 apical appendage, basal cell thin-walled (Fig. 1b). Molecular taxonomy of M. karstenii was identified by nBLAST analysis, ITS sequence was submitted in GenBank, NCBI, USA with an accession number of JN222973. Phylogenetic tree of $M$. karstenii was constructed by MEGA6 using with maximum parsimony method with additional of 100 randomly sequences. The monophyletic group of M. karstenii showing 100 of similarities with other Monochaetia species. Colletotrichum gloeosporioides from coelomycetes and Amanita muscaria from basidiomycetes were used for an out group (Fig. 1c).

Fungal biomass was observed in twelve different liquid media for enhancing biomass production and antibacterial activity were recorded against $S$. aureus and $K$. pnemoniae.
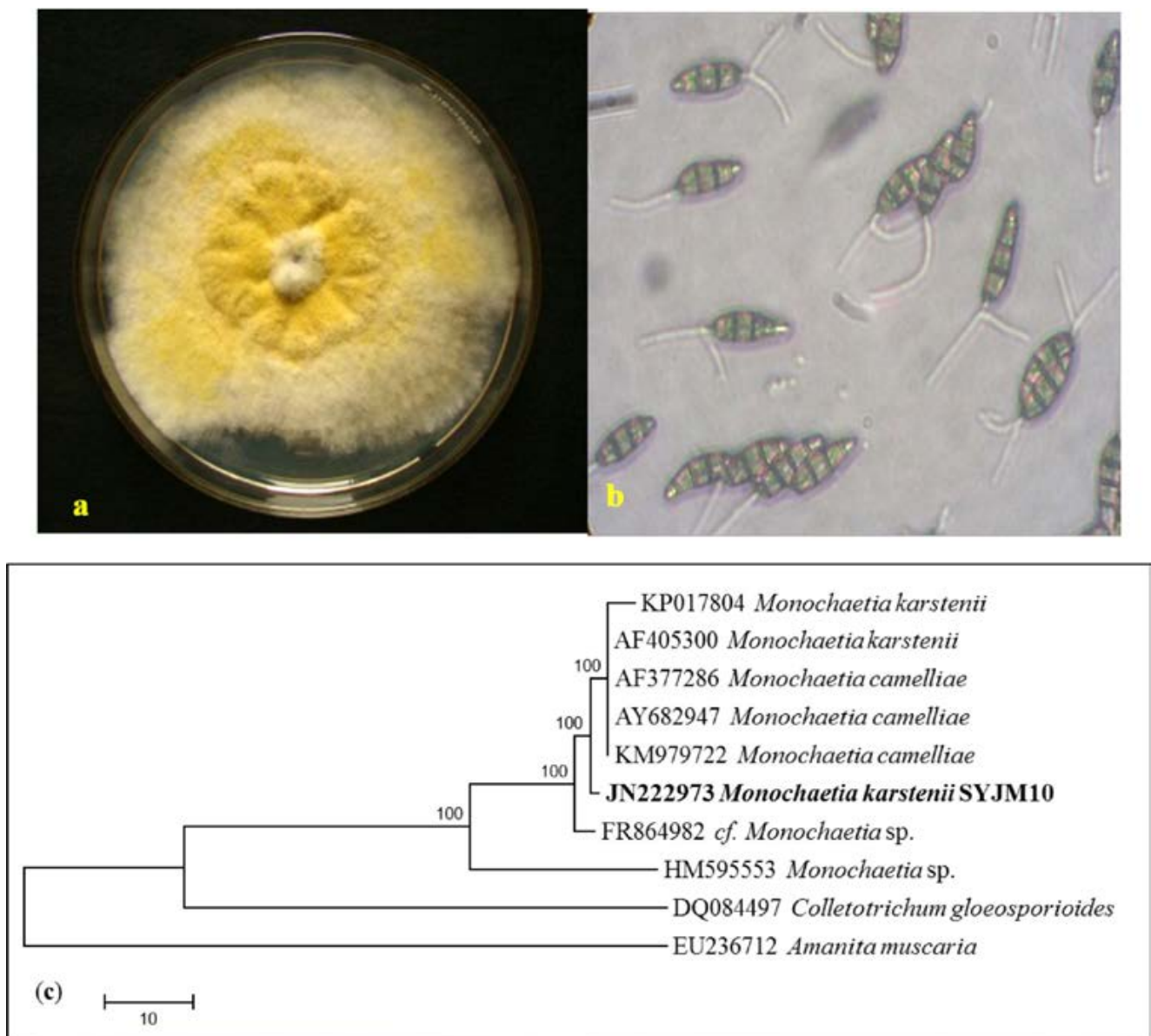

Fig. 1. (a) Culture plate showing growth of M. karstenii on MTA medium; (b) Spore morphology showing mature conidia of M. karstenii in $40 \mathrm{X}$; (c) Phylogenetic relationship of M. karstenii by Maximum parsimony analysis 
Among the media used, MTB $(1.07 \mathrm{~g})$ showed maximum biomass production followed by PDB $(0.92 \mathrm{~g})$, PDYEB $(0.65 \mathrm{~g})$ and M1D $(0.77 \mathrm{~g})$. The ethyl acetate fungal extract of MTB showed best inhibition against S. aureus and $K$. pneumoniae (Fig. 2). Relatively, Timnick et al. ${ }^{26}$ reported that MTB medium supported the growth of Melanconium belonging to the order of Melanconiales.

There has been substantial challenge to supply the essential nutrients favouring production of secondary metabolites ${ }^{27}$. So, the present study deals with optimization of $M$. karstenii for highest biomass production using different media components of carbon, nitrogen, mineral, aminoacid and vitamin sources. The effect of different carbon sources, the highest biomass (1.25 g) was observed in glucose followed by fructose, sucrose and maltose. There is no significant biomass observed in xylose, sorbitol, mannitol, galactose and lactose (Fig.3a). Similar observation

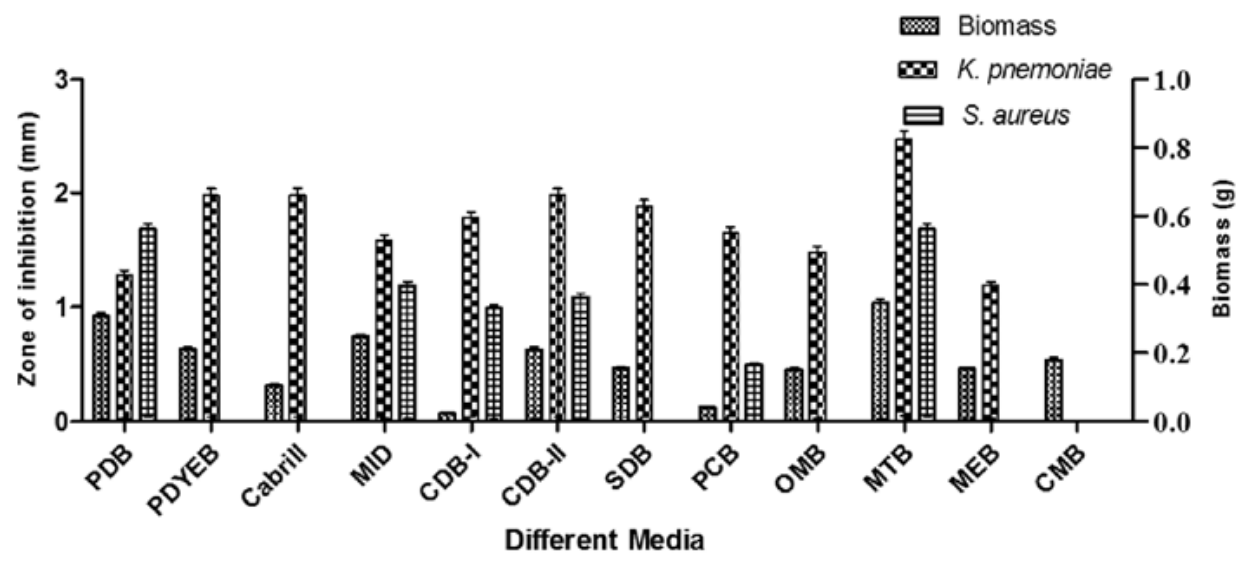

Fig. 2. M. karstenii growth comparison in various media and antibacterial activity.
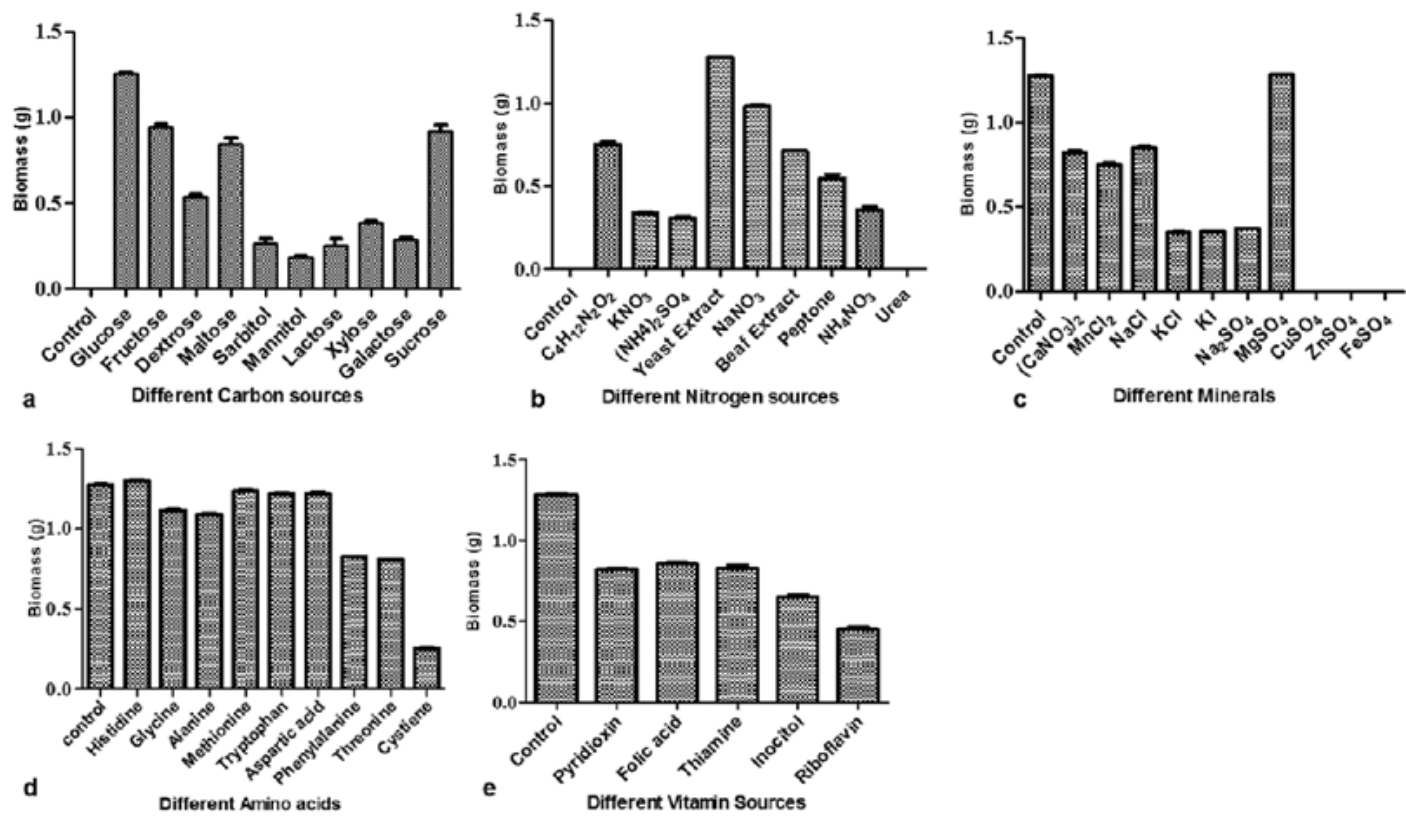

Fig. 3. Growth of M. karstenii in different chemical parameters: (a) carbon; (b) nitrogen; (c) mineral; (d) amino acid; (e) Vitamin; without respective nutrition containing medium refers to the control 
was confirmed by Ranzoni ${ }^{28}$ stating that Anguillo sporalongissima and $A$. gigantea growth were supported with glucose as best carbon source. Our study shows, minimum biomass was observed in lactose. Supporting this, Sati and Bisht ${ }^{29}$ observed that very least growth using lactose as carbon source for Tetracheatun elegans and Tetracladium marchalianum.

Among the nine different nitrogen sources, yeast extract supported highest biomass $(1.28 \mathrm{~g})$ followed by sodium nitrate, ammonium tartarate, beef extract and peptone. No growth was observed in urea and control (Fig. 3b). Similar to our study results, Fusarium sp. (SS2) has elevated level of antibacterial compounds and biomass produced in medium supplemented with yeast extract ${ }^{30}$. Different mineral sources, the constant biomass production (1.28 g) was observed in magnesium sulphate followed by calcium nitrate, manganese chloride and sodium chloride. Growth was not exhibited in copper sulphate, ferrous sulphate and zinc sulphate (Fig. 3c). Notably, constant result was observed when added magnesium sulphate in basal and optimized medium. This results seem to be similar to Jonathan and Fasidi ${ }^{31}$ reoprted Psathyerella atroiumbonata best mycelial growth when supplemented with magnesium and calcium. Similarly, Sehgal and Anand ${ }^{32}$ also observed that magnesium sulphate supported the growth of Cordyseps militaris.
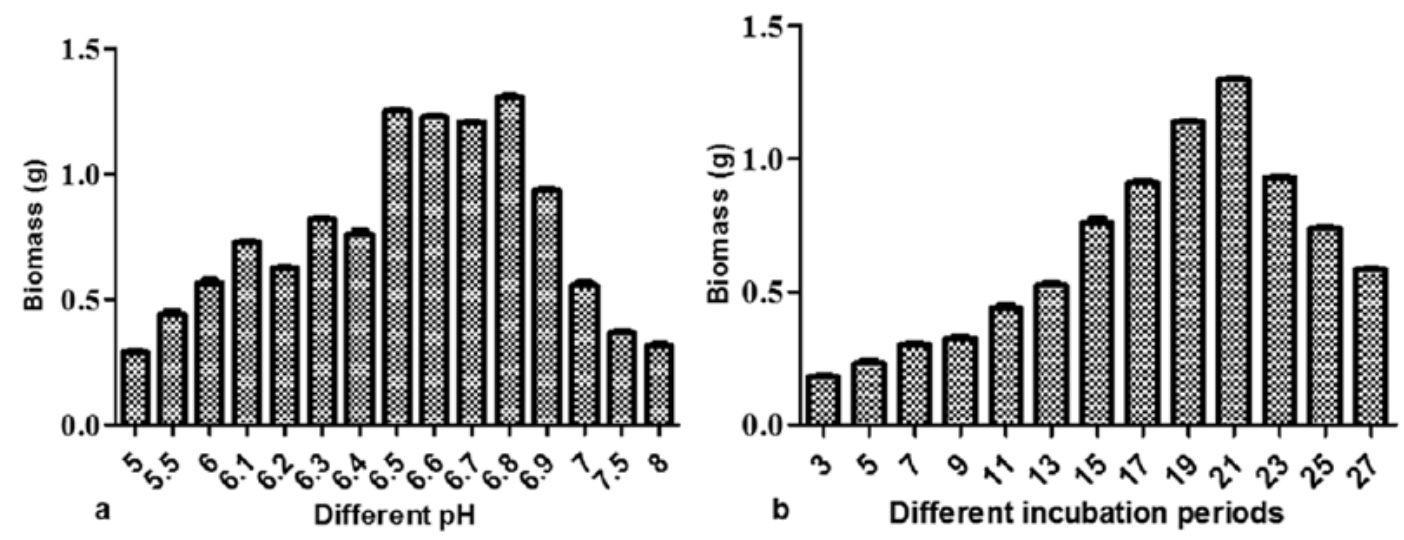

Fig. 4. Growth of $M$. karstenii in different physical parameters: (a) $\mathrm{pH}$; (b) incubation periods

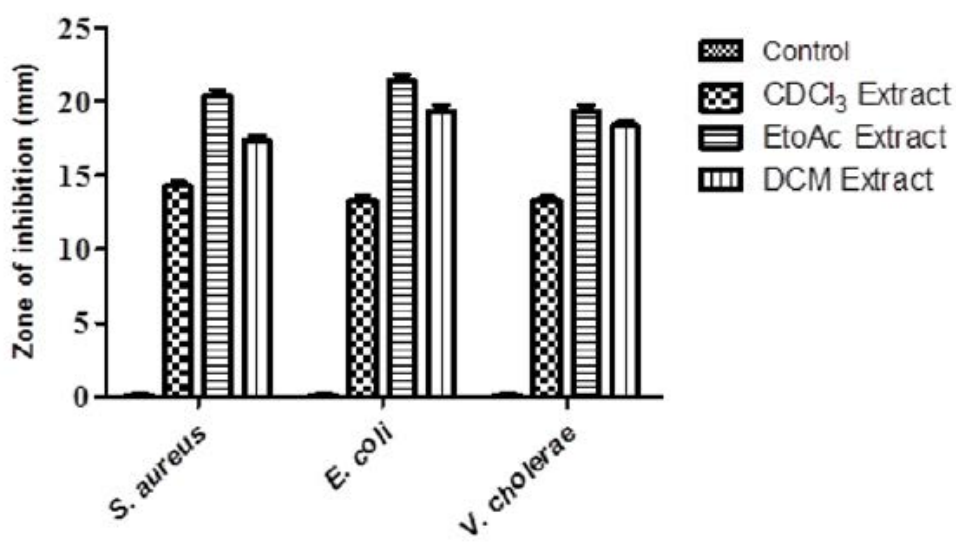

Fig. 5. Antibacterial activity of different solvent extracts of $M$. karstenii; control $-0.4 \% \mathrm{DMSO} \mathrm{CDCl}_{3}$ extract chloroform; EtoAc extract - ethyl acetate; DCM extract -dichloromethane. 
From amino acid sources, the highest biomass (1.29 g) was observed in histidine followed by glycine, alanine, methionine, tryptophan, aspartic acid (Fig.3d). Related result was observed in the growth of Colletotrichum gloeosporioides ${ }^{33}$. Vitamin supplement did not support the growth of $M$. karstenii in our studies (Fig.3e) which is connected to reports of Painter ${ }^{34}$ with studies on Geotrichum sp. and F. aqueductum, but Trichosporon cutaneum showed maximum growth in medium containing thiamine, whereas Sepedonium sp. requires both thiamine and biotin.

The $M$. karstenii growth effects at different $\mathrm{pH}$ were studied. The stable biomass $(1.29 \mathrm{~g})$ was observed in pH 6.8 followed by $\mathrm{pH} 6.5,6.6$ and 6.7. Poor growth was observed in $\mathrm{pH} 5.0,5.5,7.5$ and 8. This result suggested that optimum $\mathrm{pH}$ of the medium was 6.8 for M. karstenii (Fig.4a) in altered optimized MTB medium. P. thea $e^{35}$ showed good growth at $\mathrm{pH}$ 6.7. $M$. karstenii was harvested at different incubation periods showed fluctuations in growth. The growth increased gradually from $5^{\text {th }}$ day to $21^{\text {st }}$ day and declined later. These results indicated that the constant growth $(1.29 \mathrm{~g})$ was achieved on $21^{\text {st }}$ day (Fig. 4b).Connectively, Choi et al. ${ }^{36}$ reported maximum production of anticancer compound level was achieved after 21 days.

Present study indicates that, the optimized MTB medium per litre for $M$. karstenii with composition of potassium dihydrogen phosphate $-1 \mathrm{~g}$, glucose $-20 \mathrm{~g}$, magnesium sulphate $-0.5 \mathrm{~g}$, yeast extract $-2.8 \mathrm{~g}$, trace elements (Zinc - $200 \mu \mathrm{g}$, Iron - $200 \mu \mathrm{g}$, manganese - $100 \mu \mathrm{g}$ ) and histidine $50 \mathrm{mg}$ with pH 6.8 for 21 days showed best yield and compounds. The biomass of $13.16 \mathrm{~g}$ from per litre of optimized medium was supported

Table 1. Antioxidant activities of M. karstenii

\begin{tabular}{lccc}
\hline \multirow{2}{*}{$\begin{array}{l}\text { Fungal ethyl acetate } \\
\text { extract }(\mu \mathrm{g} / \mathrm{ml})\end{array}$} & \multicolumn{3}{c}{$\%$ of Inhibitions } \\
\cline { 2 - 4 } & DPPH & ABTS & Total antioxidant \\
\hline 50 & $8.99 \pm 0.17$ & $18.46 \pm 0.36$ & $22.50 \pm 0.45$ \\
100 & $40.79 \pm 0.81$ & $49.71 \pm 0.99$ & $44.28 \pm 0.88$ \\
150 & $53.34 \pm 1.06$ & $74.60 \pm 1.49$ & $52.85 \pm 1.05$ \\
200 & $71.40 \pm 1.42$ & $98.50 \pm 1.99$ & $60.00 \pm 1.20$ \\
250 & $89.30 \pm 1.78$ & $99.60 \pm 2.49$ & $75.31 \pm 1.50$ \\
Ascorbic acid $(100 \mu \mathrm{g})$ & - & $79.72 \pm 1.59$ & $95.65 \pm 1.91$ \\
Quercetin $(10 \mu \mathrm{g})$ & $92.78 \pm 1.85$ & - & - \\
$\mathrm{IC}_{50}$ value & $140.60 \pm 2.81$ & $100.58 \pm 2.01$ & $141.91 \pm 2.83$ \\
\hline
\end{tabular}

Values are expressed as mean \pm S.E.M of 3 replicates; - indicates not tested

Table 2. Bioactive compounds from M. karstenii

\begin{tabular}{|c|c|c|c|c|c|}
\hline No & Name of the compounds & $\begin{array}{l}\text { Retion } \\
\text { Time }\end{array}$ & $\begin{array}{l}\text { Peak } \\
\text { Area (\%) }\end{array}$ & $\begin{array}{l}\text { Mass } \\
(\mathrm{g} / \mathrm{mol})\end{array}$ & $\begin{array}{l}\text { Molecular } \\
\text { formula }\end{array}$ \\
\hline 1 & Styrene & 21.77 & 0.44 & 104.15 & $\mathrm{C}_{8} \mathrm{H}_{8}$ \\
\hline 2 & 2- Propenoic acid, 3- Phenyl/cinnamic acid & 24.03 & 11.19 & 148.161 & $\mathrm{C}_{9}^{8} \mathrm{H}_{8}^{8} \mathrm{O}_{2}$ \\
\hline 3 & $2(1 \mathrm{H})$ - Pyridinone, 1- ethyl & 26.02 & 1.43 & 123.152 & $\mathrm{C}_{7}^{9} \mathrm{H}_{9}^{8} \mathrm{NO}$ \\
\hline 4 & $\begin{array}{l}\text { 1-[ } \alpha-(1 \text { - adamantyl) benzylidenyl] } \\
\text { thiosemicarbazide }\end{array}$ & 26.67 & 1.59 & 313.463 & $\mathrm{C}_{18} \mathrm{H}_{23} \mathrm{~N}_{3} \mathrm{~S}$ \\
\hline 5 & 2-Isoxazoline, 3-phenyl- & 26.98 & 4.62 & 147.174 & $\mathrm{C}_{9} \mathrm{H}_{9} \mathrm{NO}$ \\
\hline 6 & Cis- 1- chloro- 1, 3- dimethyl silacyclohexane & 27.65 & 3.14 & 162.73 & $\mathrm{C}_{7} \mathrm{H}_{15} \mathrm{ClSi}$ \\
\hline 7 & $1 \mathrm{H}, 1,5$ - Benzodiazepine, $2,3,4,5$ - tetrahydro & 28.27 & 5.58 & 148.2 & $\mathrm{C}_{9} \mathrm{H}_{12} \mathrm{~N}_{2}$ \\
\hline 8 & Oxiniacic acid/Nicotinic acid N-oxide & 28.47 & 10.55 & 139.109 & $\mathrm{C}_{6} \mathrm{H}_{5} \mathrm{NO}_{3}$ \\
\hline 9 & 2, 2- dimethyl- 1 - oxa- spiro $(2,3)$ hexane & 29.46 & 9.54 & 112.172 & $\mathrm{C}_{7}^{6} \mathrm{H}_{12}^{5} \mathrm{O}^{3}$ \\
\hline 10 & Cis, 3, 5- dimethyl cyclohexanone & 29.92 & 3.18 & 126.196 & $\mathrm{C}^{8} \mathrm{H}_{14}^{12} \mathrm{O}$ \\
\hline 11 & 1- Dodecene & 30.25 & 14.38 & 168.319 & $\mathrm{C}_{12} \mathrm{H}_{24}$ \\
\hline 12 & 3- undecen-1-yne & 31.17 & 10.38 & 150.26 & $\mathrm{C}_{11}^{12} \mathrm{H}_{18}^{24}$ \\
\hline 13 & Neopentylidenecyclohexane & 32.23 & 4.86 & 152.276 & $\mathrm{C}_{11}^{11} \mathrm{H}_{20}$ \\
\hline
\end{tabular}


to produce secondary metabolites from culture filtrate. Thus providing media with necessary chemical constituents leads to accumulation of metabolites. This study revealed that optimization of these culture growth conditions were first time reported in MTB medium as well in $M$. karstenii. The extraction of chemical metabolites was carried out using, chloroform, dichloromethane and ethyl acetate separately. The antibacterial study results had inhibition zones of 20 and $21 \mathrm{~mm}$ found in ethyl acetate extract against $S$. aureus and $E$. coli respectively. Whereas for dichloromethane and chloroform extract inhibition zones found to be 19 and $18 \mathrm{~mm} ; 14$ and $13 \mathrm{~mm}$ respectively against $E$. coli and $V$. cholera respectively (Fig.5). Study results shows that ethyl acetate extract has prominent potential active principle to control ( $0.4 \%$ DMSO) growth of microbes. Xu et al. ${ }^{37}$, reported most of the bioactive compounds were obtained from ethyl acetate extract of Pestalotiopsis sp.

In this study, the fungal ethyl acetate extract was taken for in-vitro antioxidant activities. The IC ${ }_{50}$ value was obtained at 141.91, 140.60 and $100.58 \mu \mathrm{g} / \mathrm{ml}$ for total antioxidant, DPPH and ABTS radical scavenging assay compared with standard respectively (Table 1). Similarly, Sharma and Vijaya ${ }^{38}$ proved that ethyl acetate extract of Aspergillus termeus had highest antioxidant activity. Thus M. karstenii exhibited potent biological activity in ethyl acetate extract by antibacterial and antioxidant assays.

In order to find out the bioactive compounds, fungal ethyl acetate extract proceeded further for GC-MS analysis. The GCMS spectral data revealed thirteen bioactive peaks corresponding to compounds such as cyclohexenone derivatives, cinnamic acid, isooxazoline 3-phenyl-, benzodiazepine, 2propenoic acid 3-phenyl-(E)-, dodecene and 3-undecen -1-yne $(E)$, etc. were identified and reported first time from $M$. karstenii. Molecular formula, mass value, retention time and area $\%$ of chemical composition are listed in Table 2. Ambuic acid, cyclohexenone moiety, reported for its antifungal activity has been isolated from rain forest plant endophytic fungi Pestalotiopsis spp. and Monochaetia sp. ${ }^{13}$. The main components such as 1-Dodecene, neopentyllidenecyclohexane, cinnamic acid and oxiniacic acid were observed and reported for antimicrobial, antitumor, antioxidant and anti-hyperlipoproteinemic agent respectively ${ }^{39-43}$.

\section{CONCLUSION}

Overall from this study, carbon and nitrogen sources are both important for growth of $M$. karstenii. Nitrogen is essential for the growth of fungus and carbon has an even greater importance. It is necessary for energy production and synthesis of various cell wall lipids. Studies confirmed that the ethyl acetate extract of $M$. karstenii have potent antibacterial and antioxidant activity. GC-MS studies have revealed the presence of interesting biocompounds for curing bacterial, fungal, cancer and several diseases. Thus further research is in progress to isolate the novel bioactive compounds by chromatographic and spectroscopic methods.

\section{ACKNOWLEDGEMENTS}

Author SY thankful to Dr. K. Pushkala, Professor, S.D.N.B. Vaishnav College for Women, Chromepet, and Chennai for helping in collection of the plant samples. Author (SY) grateful to University Grants Commission of Rajiv Gandhi National Fellowship (UGC-RGNF) and UGC-visiting fellowship (NRCBS), Government of India for financial support. Author SY thankful to Late Prof. J. Muthumary, Mentor, CAS in Botany for invaluable guidance, constant support and encouragement, constructive criticism of my research work and Prof. R. Rengasamy, Director, CAS in Botany, for providing necessary facilities.

\section{CONFLICT OF INTEREST}

The authors declare that there is no conflict of interest.

\section{AUTHORS' CONTRIBUTION}

YS-Methodology, visualization, investigation and writing-original draft preparation; RS- supported for GC-MS analysis, Editing and reviewing of the manuscript, LB- contributed for anti-oxidant assay; KS - Editing and reviewing of the manuscript.

\section{FUNDING}

None. 


\section{DATA AVAILABILITY}

The datasets analysed during the current study are available in this manuscript and NCBI database repository, Accession No: JN222973.

\section{ETHICS STATEMENT}

This article does not contain any studies with human participants or animals performed by any of the authors.

\section{REFERENCES}

1. Wakhungu WW. Economic and practical food and beverage. Health applications of mycology, Biological Science, School of Pure \& Applied Advanced Mycology. Pwani University; 2016.

2. Hirakawa $\mathrm{H}$, Tomita $\mathrm{H}$. Interference of bacterial cell-tocell communication: a new concept of antimicrobial chemotherapy breaks antibiotic resistance. Front Microbiol. 2013;4:1-14. https://doi.org/10.3389/ fmicb.2013.00114

3. Arumugam GK, Srinivasan SK, Joshi G, Gopal D, Ramalingam K. Production and characterization of bioactive metabolites from piezotolerant deep sea fungus Nigrospora sp. in submerged fermentation. J. App. Microbiol. 2014;118: 99-111. https://doi. org/10.1111/jam.12693

4. Shukla S, Harshita S, Akhilesh KP. Optimization of various parameters for production of antimicrobial compounds by Fusarium roseum FGCC\#61. W. J. Pharm. Pharma Sci., 2014; 3: 890-905.

5. Vander Molen KM, Raja HA, El-Elimat T,Oberlies NH. Evaluation of culture media for the production of secondary metabolites in a natural products screening program. AMB Express. 2013;3:71. https://doi. org/10.1186/2191-0855-3-71

6. Wang L, Ridgway D, Gu T, Moo-Young M. Bioprocessing strategies to improve heterologous protein production in filamentous fungal fermentations. Biotechnol Adv. 2005;23:115-129. https://doi.org/10.1016/j. biotechadv.2004.11.001

7. Leite LG, Alves SB, Batista FA, Roberts DW. Effect of salts, vitamins, sugars and nitrogen sources on the growth of three genera of Entomophthorales: Batkoa, Furia, and Neozygites. Mycol Res. 2003;7:872-878. https://doi.org/10.1017/S0953756203007974

8. Thakur DB, Bora TC, Bordoloi GN, Mazumdar S. Influence of nutrition and culturing conditions for optimum growth and antimicrobial metabolite production by Streptomyces sp.201. J Med Mycol. 2009;19:161-167. https://doi.org/10.1016/j. mycmed.2009.04.001

9. Stanbury PF, Whitaker A, Hall SJ. Media for industrial fermentations. In: Stanbury PF Whitaker A, HallSJ (eds.) Principles of fermentation technology, Elsevier Science Ltd., Pergamon Oxford, New York, Tokyo. 1995;93-122. https://doi.org/10.1016/B978-0-08-036131-4.500092

10. Mehrotra RS, Aneja KR. An introduction to mycology. New Age International $(P)$ limited, Publishers, New
Delhi. 1990;714.

11. Silva ND, Phookamsak R, Maharachchi kumbura SSN, Thambugala KM, Bhat DJ, Al-Sadi AM, Lumyong S, Hyde KD. Monochaetia ilexae sp.nov. (Pestalotiopsidaceae) from Yunnan Province in China. Phytotaxa. 2017;29:123-132. https://doi. org/10.11646/phytotaxa.291.2.3

12. Strobel GA, Hess WM, Ford F, Sidhu RS, Yang X. Taxol from fungal endophytes and the tissue of biodiversity. J. Ind. Micro. Biotech. 1996;17:417-423. https://doi. org/10.1007/BF01574772

13. Li JY, Harper JK, Grant DM, et al. Ambuic acid, a highly functionalized cyclohexenone with antifungal activity from Pestalotiopsis spp. and Monochaetia sp. Phytochemistry. 2001;56:463-468. https://doi. org/10.1016/S0031-9422(00)00408-8

14. Komori T, Yamashita M, Tsurumi Y, Kohsaka M. Chaeticandin, A novel Papulacandin I. Fermentation, isolation and characterization. J Antibiotics. 1985;38:455-459. https://doi.org/10.7164/ antibiotics.38.455

15. Yogeswari S, Ramalakshmi S, Neelavathy R, Muthumary J. Identification and comparative studies of different volatile fractions from Monochaetia kansensis by GCMS. Global J. Pharmacology. 2012;6(2):65-71.

16. Sutton BC. The Coelomycetes: Fungi Imperfecti with pycnidia, acervuli and stromata. Commonwealth Mycological Institute, Kew, Surrey, England. 1980.

17. Moller EM, Bahnweg G, Sandermann H, Geiger $\mathrm{HH}$. A simple and efficient protocol for isolation of high molecular weight DNA from filamentous fungi, fruit bodies, and infected plant tissues. Nucleic Acids Research. 1992;20:6115-6116. https://doi. org/10.1093/nar/20.22.6115

18. Kumar S, Tamura K, Jakobsen IB, Nei M. MEGA2: Molecular Evolutionary Genetics Software. Arizona State University, Tempe, Arizona, USA. 2001. https:// doi.org/10.1093/bioinformatics/17.12.1244

19. Patel SJ, Nithin V, Pradeep S. Screening for Antimicrobial Activity of Weeds. In: The Internet Journal of Microbiology., 2007:1-7.

20. Liu X, Dong $M$, Chen X, Jiang $M$, Lv X, Zhou J. Antimicrobial activity of an endophytic Xylaria sp.YX-28 and identification of its antimicrobial compound 7-amino-4-methylcoumarin. App. Microbiol. Biotechnol. 2008;78: 241-247. https://doi. org/10.1007/s00253-007-1305-1

21. Prieto P, Pineda M, Aguilar M. Spectrophotometric quantitative of antioxidant capacity through the formation of a phosphomolybdenum complex: Specific application to the determination of vitamin E. Anal Biochem. 1999;269:337-341. https://doi.org/10.1006/ abio.1999.4019

22. Re R, Pellegrini N, Proteggente A, Pannala A, Yang $M$, Rice-Evans C. Antioxidant activity applying in improved ABTS radical cation decolorization assay. Free Radic. Bio. Med. 1999;26:1231-1237. https://doi. org/10.1016/S0891-5849(98)00315-3

23. Yen GC, Chiu-Luan H. Antioxidant effects of Dopamine and Related compounds. Biosci Biotech Biochem. 1997;61:1646-1649. https://doi.org/10.1271/ bbb. 61.1646 
24. Kharwar RN, Mishra A, Gond SK, Stierle A, Stierle D. Anticancer compounds derived from fungal endophytes: their importance and future challenges. Nat Prod Rep. 2011;28:1208-1228. https://doi. org/10.1039/c1np00008j

25. Vassiljevski NI, Karakulin BP. Fungi imperfecti Parasitici: Pars II. Melanconiales. 1950:1-680.

26. Timnick MB, Barnett HL, Lilly VG. The effect of method of inoculation of media on Sporulation of Melanconium fuligineum. Mycologia. 1952;44:141149. https://doi.org/10.1080/00275514.1952.12024 178

27. Demain AL. Regulation of secondary metabolism. In:Finklestein DB, BallC. (eds) Biotechnology of Filamentous Fungi: Technology and Products, Butterworth-Heinemann, Boston. 1992. https://doi. org/10.1016/B978-0-7506-9115-4.50011-5

28. Ranzoni FV. Nutrient requirements for two species of aquatic Hyphomycetes. Mycologia. 1951;43:130-141. https://doi.org/10.1080/00275514.1951.12024114

29. Sati SC, Bisht S. Utilization of various carbon sources for the growth of waterborne conidial fungi. Mycologia. 2006;98:678-681. https://doi.org/10.1080/15572536 .2006 .11832639

30. Radu S, Kqueen CY. Preliminary screening of endophytic fungi from medicinal plants in Malaysia for antimicrobial and antitumour activity. Malaysian J Med Sci. 2002;9:23-33.

31. Jonathan SG, Fasidi IO. Effect of carbon, nitrogen and mineral sources on growth of Psathyerella atroumbonata (Pegler), a Nigerian edible mushroom. Food Chem. 2001;22:149-483. https://doi. org/10.1016/S0308-8146(00)00265-X

32. Sehgal A, Anand S. In-vitro isolation and influence of National conditions on the mycelial growth of the Entomopathogenic and medicinal fungus Cordyceps militaris. Plant pathology Journal. 2006;5:315-321. https://doi.org/10.3923/ppj.2006.315.321

33. Tandon RN, Chandra $S$. The nutrition of Colletotrichum gloeosporioides(Penz.) Penz. and Sacc. Mycopathologica. 1962;18:213-214. https://doi.
org/10.1007/BF02051594

34. Painter HA. Factors affecting the growth of some fungi associated with sewage purification. J gen Microbial. 1954;10:177-190. https://doi.org/10.1099/0022128710-1-177

35. Subramanian S. Nutritional studies on Fusarium udum. Butler Proc Indian Acad Sci. 1961;54B:295-305.

36. Choi HK, Kim SI, Son JS, Hong SS, Lee HS, Lee HJ. Enhancement of paclitaxel production by temperature shift in suspension culture of Taxus chinensis. Enzyme Microb Technol. 2000;27:593-598. https://doi. org/10.1016/S0141-0229(00)00255-6

37. Xu J, Julia K, Jandirk S, et al. Cytosporones, coumarins, and an alkaloid from the endophytic fungus Pestalotiopsis sp. isolated from the Chinese mangrove plant Rhizophoramucronata. Bioorganic and Medicinal Chemistry. 2009;17:7362-7367. https://doi. org/10.1016/j.bmc.2009.08.031

38. Sharma R, Vijaya KBS. Isolation characterization and antioxidant potential of endophytic fungi of Ocimum sanctum Linn. (Lamiaceae). Indian J Appl Res. 2013;3:510. https://doi.org/10.15373/2249555X/JULY2013/23

39. Tayung K, Barik BP, Jha DK, Deka DC. Identification and characterization of antimicrobial metabolite from an endophytic fungus, Fusarium solani isolated from bark of Himalayan yew. Mycosphere. 2011;2:203-213.

40. Yan HC, Pu H, Zhang ZY, Song J. Evaluation of antioxidant and antitumour activities of lemon essential oil. J. Med. Plants Res. 2010;4:1910-1915.

41. Sova M. Antioxidant and antimicrobial activities of cinnamic acid derivatives. Mini Rev. Med. Chem. 2012;12:749-767. https://doi. org/10.2174/138955712801264792

42. Deng $Z$, Chengfeng $L$, Dan $L$, et al. A new cinnamic acid derivative from plant-derived endophytic fungus Pyronema sp., Natural Product Res. 2017. https://doi. org/10.1080/14786419.2017.1311890

43. Ashutosh K. Pharmacognosy and Pharmacobiotechnology. New Age International (P) limited, Publishers, New Delhi; 2003;1-879. 